\title{
GENETIC RESPONSE OF GROWING COCKERELS TO SORGHUM OFFAL SUBSTITUTE FOR SORGHUM MEAL IN A RESEARCH ENVIRONMENT
}

\author{
J. I. KPEREGBEYI AND C. S. O. OTOIKHIAN
}

(Received 5 May 2014; Revision Accepted 26 May 2014)

\begin{abstract}
One hundred and fifty (150) Day old Anak cockerel chicks were used in this study, to evaluate the effect of feeding Sorghum Offal (SO) in the bird's performance, nutrient utilization and carcass characteristics. They were distributed into five dietary treatments, with varied levels of weight for weight replacement $(2,3,4$, and 5 contained $15,35,55$ and $75 \%$ sorghum offal in place of sorghum meal) respectively. While treatment 1 with zero replacement serving as control. The response of the birds, in terms of feed intake weight gained, feed conversion efficiency, and apparent nutrient digestibility and retention were determined. The organ weights and weight of cut parts were also recorded. The result showed that weight of organs such as spleen, heart, liver, kidney and proventriculus increased significantly across the row. The study indicated that the substitution of sorghum offal for sorghum meal at levels up to $35 \%$ can be tolerated by cockerel chicks.
\end{abstract}

KEYWORDS: Nutrient utilization, digestibility, Sorghum offal, carcass characteristics, performance, response.

\section{INTRODUCTION}

The limited supply of good quality raw materials such as sorghum maize, soyabean meal, groundnut cake and cottonseed cake for the poultry feed industry has resulted in a continuous increase in the cost of production, causing a phenomena rise in the unit cost of products. Thus, these products have become too expensive for the majority of the population in "Nigeria and else where (Tewe, 2003). Sorghum offal (SO) which is a by- product of sorghum extraction is an alternative feedstuff for poultry industry. It is abundant in many tropical region and is a cheap feedstuff produced by many countries. Its use in poultry feeding has not been very much encouraged. It is therefore, important to evaluate this novel ingredient vis-a-vis its effect on the performance of growing cockerels.

There are little or no information on the use of sorghum offal in place of sorghum meal in cockerel diets, Although it is generally believed that fibres in feed are only partially utilized by poultry birds due to low digestibility of fibres by poultry birds, sorghum offal has being found to having high crude fibres of $8 \%$ with of fat content of $5 \%$, crude protein of $22 \%$ and contain more lysine and methionine than maize or sorghum meal (Olomu, 1995), With due consideration to the large quantities of sorghum produced annually in Nigeria and to the relatively low competition of sorghum offal with sorghum meal. This study was designed to evaluate carcass characteristics and growth performance of growing cockerel fed diets containing graded levels of sorghum offal as a substitute for sorghum meal.

\section{MATERIALS AND METHODS}

The experiment was carried out in the poultry unit of the School of Agriculture, Delta State Polytechnic teaching and research farm, Ozoro. A total of 150 Dayold Anak cockerels was used for 9 weeks to evaluate the substitution effect of Sorghum offal for the more competitive meal by human.

\section{Experimental Diets}

The controls diet contained $50 \%$ sorghum meal and this was replaced (weight for weight) at 15, 35, 55 and $75 \%$ and classified as treatment 2,3, 4 and 5 respectively (Table I) while the zero replacement served as control. The five treatment groups were replicated three times. Each replicate contained 10 birds each. Chicks were brooded together using the control diet, at first week of life. While the second week worked the onset of the feeding trial which was done for eight consecutive weeks. Birds were weighed weekly. Feed and water were supplied ad libitum.

\section{Digestibility Trial}

At the a weeks of age, two birds per replicate was randomly selected and place in three tier metabolic cage and was allowed to acclimatize for 3 days. Facilities for feeding and drinking were made available. After 3 days of acclimatization, faecal samples for each replicate were collected for 4 days. Samples were weighed, pooled together and then oven dried at $60^{\circ} \mathrm{C}$ until feed sample weights were constant-feed for each treatment was also weighed and oven dried to constant weight for analysis.

J. I. Kperegbeyi, School of Agriculture, Department of Agricultural Technology, Delta State Polytechnic, Ozoro Delta State, Nigeria

C. S. O. Otoikhian, Department of Animal Science Ambrose Ali University, Ekpoma, Edo State, Nigeria. 


\section{Carcass Evaluation}

At the end of the trials, one bird per replicate was randomly selected, fasted over night and slaughtered by severing the jugular veins and were thoroughly bled. Each carcass was defeathered and eviscerated carcass weight, cut parts and organ weight were determined.

\section{Chemical Analysis}

Dry matter (DM) ash, CP (NX 6.25), Crude Fat (EE) and crude fibre (CF) were determined in dry samples according to A.O.A.C. (1990)

\section{Statistical Analysis}

Data were subjected to one-way Analysis of Variance (steel and Torrie, 1980). Significantly different means were separated using Duncan's Multiple Range Test (Daniel, 1991).

\section{RESULTS AND DISCUSSION}

The chemical analysis of the experimental diet is shown in Table 1. The value obtained showed that the diets met the minimum requirements for cockerel growth and development (Olomu 1995). The results for the performance of cockerels fed experimental diets are presented in Table 2. Although, no significant difference was observed, increased levels of sorghum offal in the diets resulted in a numerical decrease in feed intake which significantly decreases final body weight. There was poor significant feed conversion efficiency of birds with increasing inclusion levels of sorghum offal in diets. The observed body weight differences and growth performance does not agree with the findings of Sanwo et al., 2006 who observed that body weight differences was due to differences in energy utilization. However, EL - Boushy and Van der Poel (1994) put the possibilities of differences in performances to the fact that digestion of crude fibre by young chicks is always very low since they may lack sufficiency digestive enzymes which would have broken down available nutrients into substances which would have been absorbed. The benefits of this study can be observed in the cost of total feed consumed per bird as shown in Table 2 and the substitution of sorghum offal for sorghum meal at $35 \%$ is most preferable if daily weight gained and dressed carcass weights are considered (weight gained - dressed carcass weight). Nutrient retention of cockerel chicks fed sorghum offal diets as shown in Table 3, decreased nitrogen retention and increased crude fibre digestibility insignificantly, however, cockerels on $75 \%$ sorghum offal inclusion levels had the lowest nitrogen retained which could have been attributes to the laxative influence of fibre resulting in increased dropping weight output and decreased nitrogen retained as observed by Action et al., (1982). Results of parts considered for carcass characteristics of the experimental birds are as shown in Table 4. Weight of organs such as spleen, heart, liver, kidney and proventiculus increased significantly across the row. This agreed with the reports of Sanwo et al., 2006 and Oluokun and Olalokun (1995) that attributed such influence to the fact that these organs became bigger in size due to indirect effect of increased metabolic activity. Likewise increase in lengths and weight of intestine was significant $(P<0.05)$ due to structural adjustment of the gastro-intestinal organs to high fibre contents of diets eaten was in line with the observations by Welch et al., (1988). The study indicated that the substitution of sorghum offal for sorghum meal at levels of up to $35 \%$ can be tolerated by cockerel chicks and will also result in more economical diets that would reduce total cost of production and increase economic returns. 
TABLE 1: COMPOSITION (\%) OF THE EXPERIMENTAL DIETS

Ingredient Replacement Levels Of Sorghum With Sorghum Offal

\begin{tabular}{lcllll} 
& 0 & 15 & 35 & 55 & 75 \\
\hline Sorghum & 50.00 & 45.00 & 35.00 & 25.00 & 15.00 \\
Sorghum offal & - & 5.00 & 15.00 & 25.00 & 35.00 \\
Wheat offal & 26.65 & 26.65 & 26.65 & 26.65 & 26.65 \\
Groundnut meal & 14.50 & 14.50 & 14.50 & 14.50 & 14.50 \\
Fish meal & 5.00 & 5.00 & 5.00 & 5.00 & 5.00 \\
Bone meal & 2.00 & 2.00 & 2.00 & 2.00 & 2.00 \\
Premix & 0.50 & 0.50 & 0.50 & 0.50 & 0.50 \\
Periwinkle shell & 1.00 & 1.50 & 1.00 & 1.00 & 1.00 \\
Salt & 0.35 & 0.35 & 0.35 & 0.35 & 0.35
\end{tabular}

Total

Calculated Analysis

Crude Protein (\%)

Crude Fibre (\%)

$\mathrm{Me}(\mathrm{Kcal} / \mathrm{Kg})$

Determined Analysis

Dry Matter(\%)

Crude Protein (\%)

Crude Fibre (\%)

Ether Extract (\%)

Ash (\%)
100.00

19.17

5.89

2433.31

92.51

20.20

4.75

2.04

5.04
100.00

19.59

6.07

2353.81

91.67

19.60

5.85

3.54

7.92
100.00

20.89

6.61

2236.81

92,26

91.45

91.72

20.89

22.19

23.49

6.34

6.86

7.49

3.05

1.89

3.41

8.64

6.46

7.31

Table 2: Performance characteristics of experimental birds

\begin{tabular}{lllllll}
\hline & \multicolumn{7}{c}{ Replacement levels of Sorghum with SO (\%) } \\
Parameters & 0 & 15 & 35 & 55 & 75 & SEM \\
\hline Initial live wt (g/bird) & 93.55 & 88.00 & 90.47 & 85.03 & 96.23 & 18.74 \\
Final body wt (g/bird) & $937.60^{\mathrm{a}}$ & $850.00^{\mathrm{ab}}$ & $905.70^{\mathrm{a}}$ & $807.9^{\mathrm{ab}}$ & $768.8^{\mathrm{b}}$ & 83.48 \\
Total weight gain (g/bird) & $844.05^{\mathrm{a}}$ & $762.00^{\mathrm{a}}$ & $815.23^{\mathrm{a}}$ & $722.87^{\mathrm{ab}}$ & $672.37^{\mathrm{b}}$ & 72.77 \\
Daily feed intake (g/bird) & $16.90^{\mathrm{a}}$ & $15.02^{\prime}$ & $15.86^{\mathrm{a}}$ & $13.47^{\mathrm{bc}}$ & $12.87^{\mathrm{C}}$ & 1.96 \\
Feed conversion ration & 4.03 & 3.91 & 2.96 & 3.83 & 3.74 & 0.46 \\
Total feed consumed (kg/bird & 3.40 & 2.68 & 2.42 & 2.77 & 2.53 & 0.05 \\
Cost of feed/kg/ ${ }^{*}$ 4) & $36.08^{\mathrm{a}}$ & $34.23^{\mathrm{s}}$ & $35.68^{\mathrm{a}}$ & $32.07^{\text {ab }}$ & $29.27^{\mathrm{b}}$ & 2.72 \\
Tota! cost of feed consumed per & & & & & & \\
Bird $(\mathrm{N})$ & 122.67 & 91.74 & 86.35 & 88.83 & 74.05 & 5.08 \\
& & & & & & \\
\hline
\end{tabular}

a,b,c = Means within the same row with different superscripts differ significantly $(\mathrm{P}<0.05)$. SEM = Standard Error of Means.

$\mathrm{SO}=$ Sorghum Offal. 
Table 3: Nutrient utilization of experimental birds fed so diets

\begin{tabular}{|c|c|c|c|c|c|}
\hline \multirow[b]{2}{*}{ Parameters (g/bird) } & \multicolumn{4}{|c|}{ Replacement levels of Sorghum with SO (\%) } & \multirow[t]{2}{*}{ SEM } \\
\hline & $0 \quad 15$ & 35 & 55 & 75 & \\
\hline Crude fibre digestibility & $72.26^{a}$ & $74.02^{\mathrm{a}}$ & $58.32^{b}$ & $32.46^{C}$ & 6.25 \\
\hline Nitrogen retention Ether extrac & $81.26^{\mathrm{a}}$ & $78.41^{\mathrm{a}}$ & $55.01^{\mathrm{b}}$ & $26.70^{\mathrm{C}}$ & 6.74 \\
\hline digestibility Total Digestibilit) & $68.27^{\mathrm{bc}}$ & $70.62^{b}$ & $76.02^{\mathrm{a}}$ & $39.42^{\mathrm{d}}$ & 7.04 \\
\hline Nutrient (TDN) & $85.58^{\mathrm{a}}$ & $56.79^{\mathrm{b}}$ & $50.06^{\mathrm{C}}$ & $46.08^{\mathrm{d}}$ & 4.67 \\
\hline
\end{tabular}

a,b,c,d Means values in a row with different superscripts are significantly different. SEM: Standard Error of Means.

SO: Sorghum Offal.

Table 4: Carcass Characteristics

\begin{tabular}{|c|c|c|c|c|c|c|}
\hline \multirow[b]{2}{*}{ Parameter } & \multicolumn{5}{|c|}{ Replacement level of Sorghum with SO } & \multirow[b]{2}{*}{ SEM } \\
\hline & 0 & 15 & 35 & 55 & 75 & \\
\hline Live weight (g) & 937.60 & 850.00 & 905.70 & 807.9 & 768.8 & 83.48 \\
\hline Dressed wt (g) & $839.60^{a}$ & $800.00^{\mathrm{a}}$ & $820.45^{\mathrm{b}}$ & $732.22^{b}$ & $699.9^{\mathrm{C}}$ & 62.86 \\
\hline Eviscerated wt & 0.26 & 1.04 & 0.89 & 0.78 & 0.08 & 0.02 \\
\hline \multicolumn{7}{|l|}{ Organs $^{1}$} \\
\hline Liver & 2.87 & 2.67 & 2.36 & 3.41 & 2.15 & 0.24 \\
\hline Spleen & $0.28^{\mathrm{a}}$ & $0.21^{\mathrm{D}}$ & $0.19^{b}$ & $0.24^{\mathrm{b}}$ & 0.18 & 0.03 \\
\hline Heart & 0.46 & 0.66 & 0.68 & 0.70 & 0.59 & 0.06 \\
\hline Lungs & 0.48 & 0.61 & 0.59 & 0.71 & 0.47 & 0.05 \\
\hline Kidneys & 0.89 & 0.71 & 0.51 & 0.74 & 0.85 & 0.12 \\
\hline Gizzard & 3.36 & 3.68 & 3.55 & 3.60 & 3.34 & 0.27 \\
\hline Proventiculus & 0.70 & 0.72 & 0.68 & 0.65 & 0.75 & 0.08 \\
\hline Wt. Of small intestine & 5.89 & 6.25 & 6.38 & 7.20 & 5.70 & 1.46 \\
\hline Length of large intestine & 1.05 & 1.27 & 1.40 & 1.44 & 1.52 & 0.22 \\
\hline \multicolumn{7}{|l|}{ Cut- cup parts } \\
\hline Head & 4.09 & 4.56 & 4.71 & 4.86 & 5.07 & 0.07 \\
\hline Shanks & 4.98 & 5.36 & 5.48 & 5.72 & 5.21 & 0.46 \\
\hline Neck & 4.00 & 5.08 & 5.13 & 4.74 & 3.88 & 0.51 \\
\hline Back & 12.08 & 12.36 & 13.01 & 11.58 & 12.26 & 0.72 \\
\hline Breast plate & 12.34 & 13.47 & 13.56 & 12.56 & 12,78 & 0.94 \\
\hline Drum sticks & 17.09 & 18.08 & 18.31 & 17.54 & 16.42 & 1.08 \\
\hline Wings & 9.02 & 8.62 & 8.81 & 7.60 & 8.50 & 0.60 \\
\hline
\end{tabular}

a,b,c: Means within the same row with different superscript differ significantly $(P>0.05)$.

SEM: Standard Error of Means.

SO: Sorghum Offal.

1,2: \% of liveweight. 


\section{REFERENCES}

Action, J. C., Breyer, L and Statter Lee, L. D., 1982. Effects of the Dietany fibre constituents on the in- vitro digestibility of casein J.fd Sci (47): 556.

AC, A. O., 1990. Association of Official Analytical chemists, Washinghum D.C. 15th edition.

Daniel, W. W., 1991. Bi@statistics, a foundation for analysis in the health science J. Wisky and Sons, New York.

El Blushy, A. R and Van Der Poel, A. F. B., 1994. Poultry feed from waste: Processing and use published by chapna and Hall, e-t Boundary Road, London SE $18 \mathrm{HN}$.

Ojewola, G. S and Ozuo, U. K., 2006. Evaluation of Palm Kernel Meal as Substitute for soyabean in the diet of growing cockerels, International Journal of Poultry Science 5, (5): $401-403$.

Olomu, J. M., 1995. Monogastic Animal: nutrition principles and practice. A jachem puDlication Benin, Nigeria. $320 \mathrm{pp}$
Oluokun, J. A and Olalokun, E. A., 1999. The effects of graded level of brewers spent grains and kolanut pod meal on the performances characteristics and carcass quality of rabbits. Nig. J. Amin, (20): 74 - 97.

Sanwo, K. A., lyayi, E. A and Olubamiwa, A. O., 2006. Performance and carcass characteristics of Cockerels fed graded levels of Kolanut, (Levels of Kolanut (cola nitida) pcd husk/ Poult. 5c/. (4):34-38

Steel, K. G. D and Torrie, J. H., 1980. Principles and procedures of statistics McGraw Hill, New York, $137-269$

Tewe, O. O., 2003. Economics of the commercial utilization of local and Animal alternative feed resource proc. of the 28th Annual conf. Of the Nigeria society for production (28): 466-468

Welch, R. W., Peterson, D. M and Schram, L. B., 1988. Hypochloric effect of oat brain functions in chicks. Nutri. Kept., 38, (3): 55. 